\title{
Human mobility and settlement patterns from eight EU countries to the Italian regions of Lombardy, Veneto, Tuscany, Lazio and Sicily
}

\author{
Armando MONTANARI ${ }^{1}$ and Evelina PALUZZI²
}

\begin{abstract}
Mobility within the EU is increasing with the emergence of a culture of Europeanism, ease of movement and the affordability of travel. Personal mobility joins the mobility of goods, financial markets and financial transactions. The situation has not always been positive, partly because of the economic crisis of 2008 and later; the construction of Europe, far from being complete, continues to encounter obstacles and difficulties. The current migration crisis is one of the strongest motivations for analysing the phenomenon of human mobility in the EU. This article considers the phenomenon of migration in five regions of Italy (Lombardy, Veneto, Tuscany, Lazio and Sicily) by citizens of countries that predominantly experience emigration (Latvia, Romania, Slovakia), immigration (Germany, Sweden, the UK) and countries like Italy where flows of both emigration and immigration are common (Ireland and Spain). The study uses regional units defined not in relation to the history of Europe over the centuries but in relation to the labour market (Labour Market Areas) identified by the National Institute of Statistics (Istat) on the basis of a contemporary parameter related to commuting. This new division of areas in relation to contemporary economic and social situations has made it possible to focus on the actual presence of immigrants by nationality and age in areas that are smaller and which more clearly demonstrate the reasons that explain mobility for production and mobility for consumption.
\end{abstract}

Keywords: human mobility, settlement patterns, labour market area, international retirement migration, return migration

\section{Introduction}

There are approximately 5 million foreign nationals currently living in Italy, with the pressing problems and opportunities that follow. Most foreigners arriving in a host country are driven by reasons related to a state of necessity or conditions difficult to withstand in their countries of origin (Montanari, A. and Cortese, A. 1993). However, part of the foreign presence in Italy has a long history of settlement, mainly tied to the appeal of culture and tourism, the manifestation of the Bel Paese's inviting pull on some groups, such as the English or the Germans (KING, R. and Patterson, G. 1998; King, R. et al. 1998). To tell the whole story, though, we have recently seen an increasingly established number of
EU foreigners, especially Britons, choosing to settle in Italy, not only to 'age' in the sun but also to start entrepreneurial activities. According to the Unioncamere report, there are more than 10,000 British entrepreneurs in Italy. Nearly a fourth have chosen Lombardy for their companies, but significant portions of this business community are also found in Lazio (14\%) and Tuscany (10\%). The sector enterprises run by British immigrants represent a significant portion of the market and include trade $(19 \%)$, manufacturing $(10 \%)$, and accommodation and food services $(9 \%)$.

This research is part of the European project, HORIZON 2020 Youth Mobility: Maximizing Opportunities for Individuals, Labour Markets and Regions in Europe (YMOBILITY), the goal of which is to exam-

\footnotetext{
${ }^{1}$ Department of European, American and Intercultural Studies. La Sapienza University, Piazzale A. Moro 5, I-00185 Roma. E-mail: armando.montanari@uniroma1.it

${ }^{2}$ National Institute of Statistics (Istat), Viale Oceano Pacifico 171, I-00144 Roma. E-mail: paluzzi@istat.it
} 
ine the mobility of young people between the three groups of EU countries chosen for their significance mainly as countries of emigration: Latvia, Romania, and Slovakia (Group 1); immigration: Germany, Sweden, and the UK (Group 3); or both inflows and outflows: Ireland, Italy and Spain (Group 2). Consideration is given to flows into Italy from the other eight countries listed. To verify and better specify what is happening in Italy, immigration is considered in two regions of the north (Lombardy and Veneto), two central regions (Lazio and Tuscany) and one in the south (Sicily).

The approximately five million foreigners residing in Italy represent an important economic factor both in their host country, where they produce some EUR 125 billion in wealth each year, as well as in their countries of origin because of their remittances and because of the relationship between Italy and their countries of origin encouraged by difficult-to-quantify political, social, economic and cultural factors.

In Italy, 48.4 percent of the population measured by census and 56.5 percent of the foreign population resides in the five regions being considered: Lombardy, Veneto, Tuscany, Lazio and Sicily, and there are significant differences between the north and the islands. The demographic relevance of the regions selected is evident, as is the significant attractiveness they exert on migration. Considering the information potential of a population census, LMAs were selected as the regional units of analysis. LMAs are an innovative way to classify the nation's regions, going beyond the traditional ad- ministrative divisions and thus making it possible to acquire a targeted and precise geographical reading of social and economic phenomena. LMAs are an analytical tool that takes a region-based approach to studying the socio-economic structure of the country. They are aggregations of adjacent districts and are the basic unit for data collection on daily commuting. Table 1 . summarizes the distribution of LMAs in the five regions and the municipalities within them, as well as the distribution of the foreign resident population and the total resident population.

Sicily contains the highest number of LMAs, but Lombardy, with 57 LMAs and the over 1,500 municipalities comprising them, is more demographically and economically significant. In fact, that one region along contains more than 16.3 percent of the total population and 23.5 percent of the foreign residents in Italy.

If the group is analysed by nationality, there is an overwhelming number of Romanians. In fact, Romanians account for one-fifth of all foreigners residing in Italy, and 55 percent of the foreigners residing in the five regions. Almost 90 percent of the sample (immigrants from the eight countries studied), in fact, are Romanians; specifically, they account for almost all of the young people (15-34 years) and about 87 percent of those between 35 and 64 years in our sample. Over 70 percent of Europeans whose countries are 'old' members of the EU are over 65; 40 percent are Germans and 21 percent are British. There is therefore a clear pattern of older age immigrants from Germany, the UK and Spain. These are those who have his-

Table 1. Distribution of residents in Labour Market Areas (LMAs) of five Italian regions

\begin{tabular}{l|c|c|c|c|c|c|c}
\hline \multicolumn{1}{c|}{ Region } & LMA & Municipalities & $\begin{array}{c}\text { LMA } \\
\%\end{array}$ & $\begin{array}{c}\text { Municipalities, } \\
\%\end{array}$ & $\begin{array}{c}\text { Total } \\
\text { population }\end{array}$ & $\begin{array}{c}\text { Foreign } \\
\text { population }\end{array}$ & $\begin{array}{c}\text { Foreigner's } \\
\text { rate, } \%\end{array}$ \\
\hline Lombardy & 57 & 1,544 & 22.5 & 48.6 & $9,704,151$ & 947,288 & 9.8 \\
Veneto & 49 & 581 & 19.4 & 18.3 & $4,857,210$ & 457,328 & 9.4 \\
Tuscany & 54 & 287 & 21.3 & 9.0 & $3,672,202$ & 321,847 & 8.8 \\
Lazio & 22 & 378 & 8.7 & 11.9 & $5,502,886$ & 425,707 & 7.7 \\
Sicily & 71 & 390 & 28.1 & 12.3 & $5,002,904$ & 125,015 & 2.5 \\
Together & 253 & 3,180 & 100.0 & 100.0 & $28,739,353$ & $2,277,185$ & 7.9 \\
\hline
\end{tabular}

Source: Authors' elaboration on ISTAT 2011 census data. 
torically been attracted to the Bel Paese more for reasons of culture and tourism than for employment. By contrast, the young age of the Romanian population in Italy indicates that Romania, which only recently joined the EU, is still strongly characterized by mobility related to production (Table 2). ity consists of various individual mobilities, as well as the ways they are interdependent and the social and economic consequences they produce. This view of mobility does not characterise humankind's ancient nomadic behaviour but rather a set of mobilities for the twenty-first century - a futuristic assess-

Table 2. Age distribution of foreign population came from eight EU member countries inside LMAs of five Italian regions* in percent

\begin{tabular}{l|c|c|c|c|c|c|c|c|c}
\hline $\begin{array}{c}\text { Age group, } \\
\text { years }\end{array}$ & Latvia & Romania & Slovakia & Ireland & Spain & Germany & Sweden & UK & $\begin{array}{c}\text { Eight } \\
\text { countries }\end{array}$ \\
\hline 15-34 & 0.3 & 95.5 & 0.7 & 0.1 & 1.1 & 1.3 & 0.2 & 0.8 & 100.0 \\
35-64 & 0.2 & 86.7 & 0.5 & 0.4 & 2.8 & 5.1 & 0.5 & 3.9 & 100.0 \\
65+ & 0.1 & 26.3 & 0.1 & 1.4 & 9.3 & 39.9 & 1.8 & 21.0 & 100.0 \\
Together & 0.2 & 89.6 & 0.6 & 0.3 & 2.1 & 4.0 & 0.4 & 2.8 & 100.0 \\
\hline
\end{tabular}

* Lombardy, Veneto, Tuscany, Lazio and Sicily together. Source: Authors' elaboration on ISTAT 2011 census data.

Regarding each nationality, there is a higher number of women in each group. Germany shows an imbalance between the genders in the younger and middle groups. That then balances out in the older group. For the British and Irish, there is a less marked gap, which further decreases as age increases. For the other nationalities, however, the numerical gap between men and women is very marked. For Spain it decreases significantly in the oldest age groups (Table 3).

This study seeks to fill the numerous gaps left by previous analyses of migration in Italy's regions. It is an original study because it does not focus only on inflows, which are quantitatively larger, but examines the differences typical of foreigners with different geographical origins, varying age groups and the spatial distributions of various nationalities and age groups. The purpose of the paper is also to use LMAs as the regional unit of analysis rather than the more traditional counties and provinces.

\section{Human migratory mobility in Europe}

URRY's book (2000) constitutes the manifesto of human mobility. It defines the various forms of human mobility, goods, images, information, communication, social relations, and economics. The concept of human mobil- ment of mobility, the implications of which have yet to be discovered (URRY, J. 2000).

The burst of technological innovations that made this mobility possible is now behind us, but its applications - and therefore waves of applied technologies - continue to develop, meaning that human mobilities are still evolving. URRY considered mobility a geographical and social phenomenon that deals with the sociology of fluids; therefore, the points of departure and arrival are no longer as relevant. Much more important are references to the speed and the viscosity of flows, and the particular features of temporary lifestyles.

Montanari, A. and Staniscia, B. (2016) assert that, of the works published since 2000, about a dozen are significant in the current debate on human mobility through the research of sociologists and geographers. Geographers Hall, C.M. and Williams, A.M. (2002) pointed out some issues typical of the mobilities paradigm from a tourism perspective: migration resulting from tourism production; migration resulting from tourism consumption; and visits to relatives and friends. There is also debate today about mobility as complex existence. This line of thinking links physical bodies "in movement" with "represented mobility" and are fundamental to understanding situations that could not be interpreted otherwise. 
Table 3. Age and gender distribution of foreign population came from eight EU member countries in all LMAs

\begin{tabular}{|c|c|c|c|c|c|c|}
\hline \multirow{2}{*}{$\begin{array}{c}\text { Age group, } \\
\text { years }\end{array}$} & \multicolumn{3}{|c|}{ Persons } & \multicolumn{3}{|c|}{$\%$} \\
\hline & Males & Females & Together & Males & Females & Together \\
\hline \multicolumn{7}{|c|}{ Latvia } \\
\hline $15-34$ & 80 & 484 & 564 & 14.2 & 85.8 & 62.1 \\
\hline $35-64$ & 40 & 292 & 331 & 12.1 & 87.9 & 36.5 \\
\hline $65+$ & 2 & 11 & 13 & 15.4 & 84.6 & 1.4 \\
\hline Together & 122 & 786 & 908 & 13.4 & 86.6 & 100.0 \\
\hline \multicolumn{7}{|c|}{ Romania } \\
\hline $15-34$ & 84,315 & 104,131 & 188,446 & 44.7 & 55.3 & 50.5 \\
\hline $35-64$ & 75,647 & 106,794 & 182,441 & 41.5 & 58.5 & 48.9 \\
\hline $65+$ & 565 & 1,843 & 2,408 & 23.5 & 76.5 & 0.6 \\
\hline Together & 160,527 & 212,768 & 373,295 & 43.0 & 57.0 & 100.0 \\
\hline \multicolumn{7}{|c|}{ Slovakia } \\
\hline $15-34$ & 228 & 1,110 & 1,338 & 17.0 & 83.0 & 54.7 \\
\hline $35-64$ & 309 & 786 & 1,095 & 28.2 & 71.8 & 44.8 \\
\hline $65+$ & 4 & 8 & 12 & 33.3 & 66.7 & 0.5 \\
\hline Together & 541 & 1,904 & 2,445 & 22.1 & 77.9 & 100.0 \\
\hline \multicolumn{7}{|c|}{ Ireland } \\
\hline $15-34$ & 100 & 138 & 238 & 42.0 & 58.0 & 18.6 \\
\hline $35-64$ & 398 & 510 & 908 & 43.8 & 56.2 & 71.1 \\
\hline $65+$ & 64 & 67 & 131 & 48.9 & 51.1 & 10.3 \\
\hline Together & 562 & 715 & 1,277 & 44.0 & 56.0 & 100.0 \\
\hline \multicolumn{7}{|c|}{ Spain } \\
\hline $15-34$ & 697 & 1,460 & 2,157 & 32.3 & 67.7 & 24.4 \\
\hline $35-64$ & 1,315 & 4,497 & 5,812 & 22.6 & 77.4 & 65.9 \\
\hline $65+$ & 255 & 599 & 854 & 29.9 & 70.1 & 9.7 \\
\hline Together & 2,267 & 6,556 & 8,823 & 25.7 & 74.3 & 100.0 \\
\hline \multicolumn{7}{|c|}{ Germany } \\
\hline $15-34$ & 825 & 1,758 & 2,583 & 31.9 & 68.1 & 15.3 \\
\hline $35-64$ & 3,522 & 7,116 & 10,638 & 33.1 & 66.9 & 63.0 \\
\hline $65+$ & 1,732 & 1,926 & 3,658 & 47.3 & 52.7 & 21.7 \\
\hline Together & 6,079 & 10,800 & 16,879 & 36.0 & 64.0 & 100.0 \\
\hline \multicolumn{7}{|c|}{ Sweden } \\
\hline $15-34$ & 76 & 276 & 352 & 21.6 & 78.4 & 23.0 \\
\hline $35-64$ & 255 & 760 & 1,015 & 25.1 & 74.9 & 66.3 \\
\hline $65+$ & 72 & 91 & 163 & 44.2 & 55.8 & 10.7 \\
\hline Together & 403 & 1,127 & 1,530 & 26.3 & 73.7 & 100.0 \\
\hline \multicolumn{7}{|c|}{ United Kingdom } \\
\hline $15-34$ & 661 & 936 & 1,597 & 41.4 & 58.6 & 13.7 \\
\hline $35-64$ & 3,452 & 4,698 & 8,150 & 42.4 & 57.6 & 69.8 \\
\hline $65+$ & 937 & 984 & 1,921 & 48.8 & 51.2 & 16.5 \\
\hline Together & 5,050 & 6,618 & 11,668 & 43.3 & 56.7 & 100.0 \\
\hline
\end{tabular}

Source: Authors' elaboration on ISTAT 2011 census data.

Hall, C.M. (2005) steps into this discussion and refers explicitly to mobilities of production (economic migrations) and mobilities of consumption. HaLL, C.M. (2005) interprets the various forms of mobility in terms of individuals who produce and consume, no longer considering those who had, until then, been considered only tourists.

Ilies, A., Dehoorne, O. and Horga, I. (2002) compared human mobility in Romania in the 1980-89 period, still under the communist regime, with the period following 1990, during 
the post-communist transition. In the first period, dominated by a severe economic crisis, internal mobility remained under the strict control of the state and international mobility was greatly reduced and mainly limited to the gathering together of ethnic groups. In the second period, internal mobility increased and new forms of international mobility were triggered, mostly outside the parameters of legality. Ivanov, I.H. (2002) mentions differences in how mobility in Bulgaria was organized before and after the fall of the communist regime. The abolition of obligatory residence did not produce the internal movements that many had feared, and that would have led to uncontrolled growth in the capital, Sofia. Instead, because of the structure of the real estate market in Sofia, psychological reasons, and a significant flow of migrants to Canada, Australia, Germany and the USA, this uncontrolled growth did not happen.

Stoenchev, N. and Stoencheva, T. (2002) mention the process of globalization of the Bulgarian economy and young people's desire to move abroad. This is evident considering the number of young people who learn foreign languages and earn degrees in subjects such as technology and medicine, and cannot find employment in Bulgaria but are in great demand abroad. BALÁž, V. and Williams, A.M. (2002) examined the transition to the market economy in Eastern Europe and identified certain countries, such as Slovakia, that constitute a "buffer zone" between the countries of Eastern and Western Europe. Their study examines Ukrainians who go to Slovakia to work and Slovaks who go to Austria to work. While the Ukrainians are mainly employed in the secondary labour market, Slovaks in Austria participate in both the primary and secondary markets, resulting in a transition shock that simultaneously produces both brain drain and brain waste. The profound changes that have affected European society have even had repercussions on phenomena that have affected the mobility of particular population groups. The fall of the communist regimes created the conditions for new forms of mobility between countries, even with very different economic systems and relationships for intergovernmental collaboration.

ILIES, A. (2005) considers the characteristics and the changes in cross-border mobility in the Romanian-Hungarian and RomanianUkrainian border regions during the communist period (1948-89) and in the postcommunist era (since 1990) with the changes caused by the Schengen Accord during the 1990s. Likewise, BoAr, N. (2005) examines the Maramures region, which lies on the border of Romania and Ukraine. Maramures was historically a unified social and economic entity; only at the end of the First World War was it divided between Romania and Ukraine. After the fall of the communist regimes and up to the beginning of the 1990s, mobility was mostly internal, mainly seasonal, tied to agricultural activities. Later, international mobility became increasingly developed, with people moving to look for better-paid work or for repatriation in the case of ethnic minorities (e.g. Jews, Germans and Hungarians). In particular, it was especially the young people who had adequate degrees and were able to speak foreign languages who emigrated. ILLÉS, S. (2006) studied the phenomenon of international elderly migration (IEM) ('pension hunters'), which was particularly important in Hungary beginning in the 1990s, as IEM accounted for more than 12 percent of immigrants during those years. This discussion illustrates some of the multifarious patterns of human mobility for labour, entrepreneurial activities, an overall better quality of life, and retirement/amenity migration taking place in Europe during the past few decades. These changes and migratory patterns have significantly affected the demographic profiles of many of Italy's regions.

\section{The Italian regions}

Analyses of migration flows generally study administrative areas, which, in Italy, according to the availability of data, may be municipalities (NUT 4), provinces (NUT 3) or regions (NUT 2). In this study, analysis was 
carried out at the level of Labour Market Areas (LMAs) known as "Sistemi Locali del Lavoro" (SLL) in Italy. As defined by Istat, these do not refer to the administrative organization of municipalities but are defined by the forms of commuting measured by the Censimento Generale della Popolazione e delle Abitazioni (General Census of Population and Housing) (http://www.istat.it/it/strumenti/territorio-ecartografia/sistemi-locali-del-lavoro).

Each LMA identifies the place where the population lives and works, and where it establishes the main social and economic activities of a given region. Also, it considers not only flows of young people (15-34 years) but also the working age population (35-64 years) and the retired population (over 65 years). This makes it possible to consider both the migratory flows focused on production for the working-age population and those focused on consumption, as is the case with a segment of young people and pensioners. Changes in Italy's economic and social system since the 1950s have made it impossible to calculate the connections across Italy's economic landscape today. This is why the concept of LMAs has been widely used in recent years by scholars in the social sciences, and there are many publications on migratory flows considered primarily as demographic movements rather than as components of a system of production.

Calafati, A.G. and Compagnucci, F. point out some inconsistencies in the use of the LMAs in the area of the Apennines and in the hilly zones of the Marche region, where the economic landscape is more compact and therefore should not be further subdivided (Calafati, A.G. 2005; Calafati, A.G. and Compagnucci, F. 2015). The LMA approach may not be suitable when applied to micro areas, but there is certainly no doubt about the system's value for comparative analyses. Birindelli, A.M., Farina, P. and Rinaldi, S. (2004) analysed the regional distribution of foreigners in Lombardy and the economic area in which they work, demonstrating how informal networks and local labour market conditions are the main causes of different concentrations of various national groups. Using LMAs, the main reason for different concentrations in the region have been identified according to level of welfare; structures for agricultural production; structures of non-agricultural production; and geographic factors.

As of 1 January 2015, there were over five million foreigners living in Italy, equivalent to more than 8 percent of the resident population (Table 4).

Nearly 60 percent of these foreigners reside in the five regions studied. The percentage of residents who are foreigners is higher than the national average in Veneto (14\%) and Lombardy $(12 \%)$, as well as in Lazio $(11 \%)$ and Tuscany $(11 \%)$. The percentage of foreign residents in Sicily (3\%) is far below the national average. Romanians make up the largest portion of foreign residents on a national level $(23 \%)$, are more numerous than average in Lazio (35\%) and Sicily (29\%) but with lower numbers in Veneto (23\%), Tuscany $(21 \%)$ and Lombardy (14\%). Other nationalities appear in much lower concentrations; citizens of Latvia are present in numbers above the national average in Sicily $(0.1 \%)$ and Lombardy $(0.6 \%)$, those from Germany in Tuscany $(1.2 \%)$ and in Sicily $(0.9 \%)$, those from the UK in Tuscany $(0.9 \%)$ and Lazio $(0.6 \%)$, those from Ireland in Lazio $(0.11 \%)$, those from Spain in Lazio (0.8\%) and in Lombardy $(0.5 \%)$; citizens of Slovakia and Sweden are not present in percentages above the national average in any of the regions studied.

The number of Romanian citizens in Italy has been increasing consistently since 2002, when the Schengen area was expanded to include Romania. They are most highly concentrated in Lazio, but also in Veneto, Piedmont and Lombardy. According to the Fondazione Moresca (2016), companies operated by foreign entrepreneurs numbered more than 551,000 in 2015 in the sectors of commerce $(38 \%)$, construction $(25 \%)$, services $(18 \%)$, manufacturing $(8 \%)$, hotels and restaurants $(8 \%)$ and agriculture (3\%). During the 2011-2015 period, companies owned by foreigners increased by 21 percent, while those owned by Italians fell by 3 percent. 
Table 4. Foreign population in five regions of Italy came from eight EU member countries on 1 January 2015.

\begin{tabular}{|c|c|c|c|c|c|c|c|}
\hline \multirow{2}{*}{\multicolumn{2}{|c|}{ Country }} & \multicolumn{5}{|c|}{ Regions } & \multirow{3}{*}{$\begin{array}{l}\text { Italy } \\
2,689\end{array}$} \\
\hline & & \multirow{2}{*}{$\begin{array}{c}\text { Lombardy } \\
662\end{array}$} & \multirow{2}{*}{$\begin{array}{c}\text { Veneto } \\
209\end{array}$} & \multirow{2}{*}{$\begin{array}{c}\text { Tuscany } \\
182\end{array}$} & \multirow{2}{*}{$\begin{array}{c}\text { Lazio } \\
180\end{array}$} & \multirow{2}{*}{$\begin{array}{c}\text { Sicily } \\
86\end{array}$} & \\
\hline I atvis & persons & & & & & & \\
\hline Latvia & $\%$ & 0.06 & 0.04 & 0.05 & 0.03 & 0.10 & 0.05 \\
\hline \multirow{2}{*}{ Romania } & persons & 159,626 & 116,056 & 83,244 & 224,537 & 50,772 & $1,331,839$ \\
\hline & $\%$ & 14.00 & 23.00 & 21.00 & 35.00 & 29.00 & 23.00 \\
\hline \multirow{2}{*}{ Slovakia } & persons & 971 & 948 & 438 & 584 & 128 & 8,351 \\
\hline & $\%$ & 0.10 & 0.20 & 0.10 & 0.10 & 0.10 & 0.20 \\
\hline \multirow{2}{*}{ Ireland } & persons & 551 & 137 & 294 & 723 & 54 & 2,598 \\
\hline & $\%$ & 0.01 & 0.03 & 0.04 & 0.11 & 0.03 & 0.05 \\
\hline \multirow{2}{*}{ Spain } & persons & 5,390 & 1,379 & 1,591 & 4,958 & 436 & 21,286 \\
\hline & $\%$ & 0.50 & 0.30 & 0.40 & 0.80 & 0.20 & 0.40 \\
\hline \multirow{2}{*}{ Germany } & persons & 6,109 & 2,477 & 4,723 & 3,863 & 1,612 & 36,749 \\
\hline & $\%$ & 0.50 & 0.50 & 1.20 & 0.60 & 0.90 & 0.70 \\
\hline \multirow{2}{*}{ Sweden } & persons & 556 & 177 & 449 & 587 & 108 & 2,968 \\
\hline & $\%$ & 0.05 & 0.03 & 0.10 & 0.10 & 0.10 & 0.10 \\
\hline \multirow{2}{*}{$\begin{array}{l}\text { United } \\
\text { Kingdom }\end{array}$} & persons & 4,609 & 1,541 & 3,545 & 4,117 & 613 & 25,864 \\
\hline & $\%$ & 0.40 & 0.30 & 0.90 & 0.60 & 0.30 & 0.50 \\
\hline \multirow{2}{*}{ Total foreigners } & persons & $1,152,320$ & 511,558 & 395,573 & 636,524 & 117,116 & $5,014,437$ \\
\hline & $\%$ & 11.50 & 14.40 & 10.50 & 10.80 & 3.40 & 8.20 \\
\hline
\end{tabular}

Source: Authors' elaboration on ISTAT 2011 census data.

\section{Labour Market Areas: regional distribution of foreigners by citizenship}

In pointing out different sizes of immigrant populations in the five Italian regions (Lombardy, Veneto, Tuscany, Lazio and Sicily), we considered both spatial density by region (Figure 1) and demographic density (Figure 2) compared to the total population. The LMAs provide information that is more effective and closer to the social and economic situation in the region, compared with the administrative areas commonly used. Nevertheless, information on major metropolitan areas such as the LMAs of Milan and Rome cannot go into the details of the neighbourhoods in which the individual nationalities are more concentrated and numerous.

Romanians are the most numerous immigrants from Group 1 countries. In terms of spatial density, they are found in the more industrialized area of the Po Valley, with the largest concentrations in the LMAs of the urban areas of Milan, Verona and Padua, in the northern part of Tuscany, the Arezzo LMA and some LMAs around Rome. As a percentage of the population, the number of Romanians is highest in manufacturing hubs in smaller centres that specialize in specific industrial products. Examples include Stradella, where the largest publishing logistics warehouse in Europe is located; Cittadella, Castelfranco Veneto, home to a large national telecommunications company; Bibbiena in Tuscany; Civita Castellana, where the manufacture of Italian ceramic bathroom fixtures is concentrated; Pomezia in Lazio; and Vittoria, greenhouse farming, produce processing and the largest fruit and vegetable market in Italy, in Sicily. By region, the greatest densities of immigrants from Latvia are found in the LMAs of Como and Desenzano del Garda, and of Slovaks in the LMA of Milan. By percentage of the population, Latvian immigrants are most concentrated in the LMA of Desenzano del Garda, which overlooks Lake Garda, while Slovak immigrants are most concentrated in the LMA of Villafranca near Verona. 


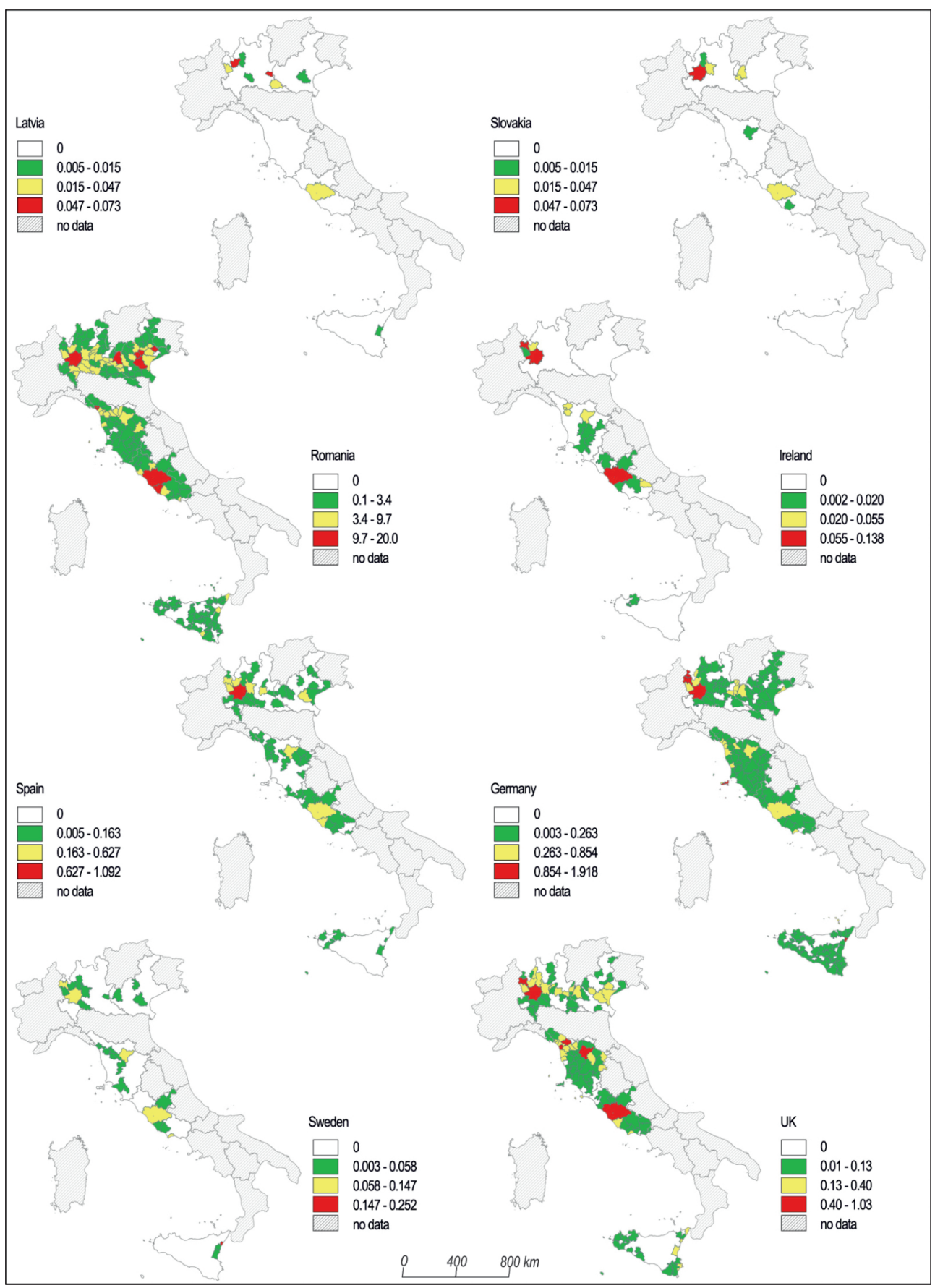

Fig 1. Immigrants per $\mathrm{km}^{2}$ from 8 EU-member countries to LMA of Lombardy, Veneto, Tuscany, Lazio and Sicily. Source: Compiled by the authors on Istat census data. 


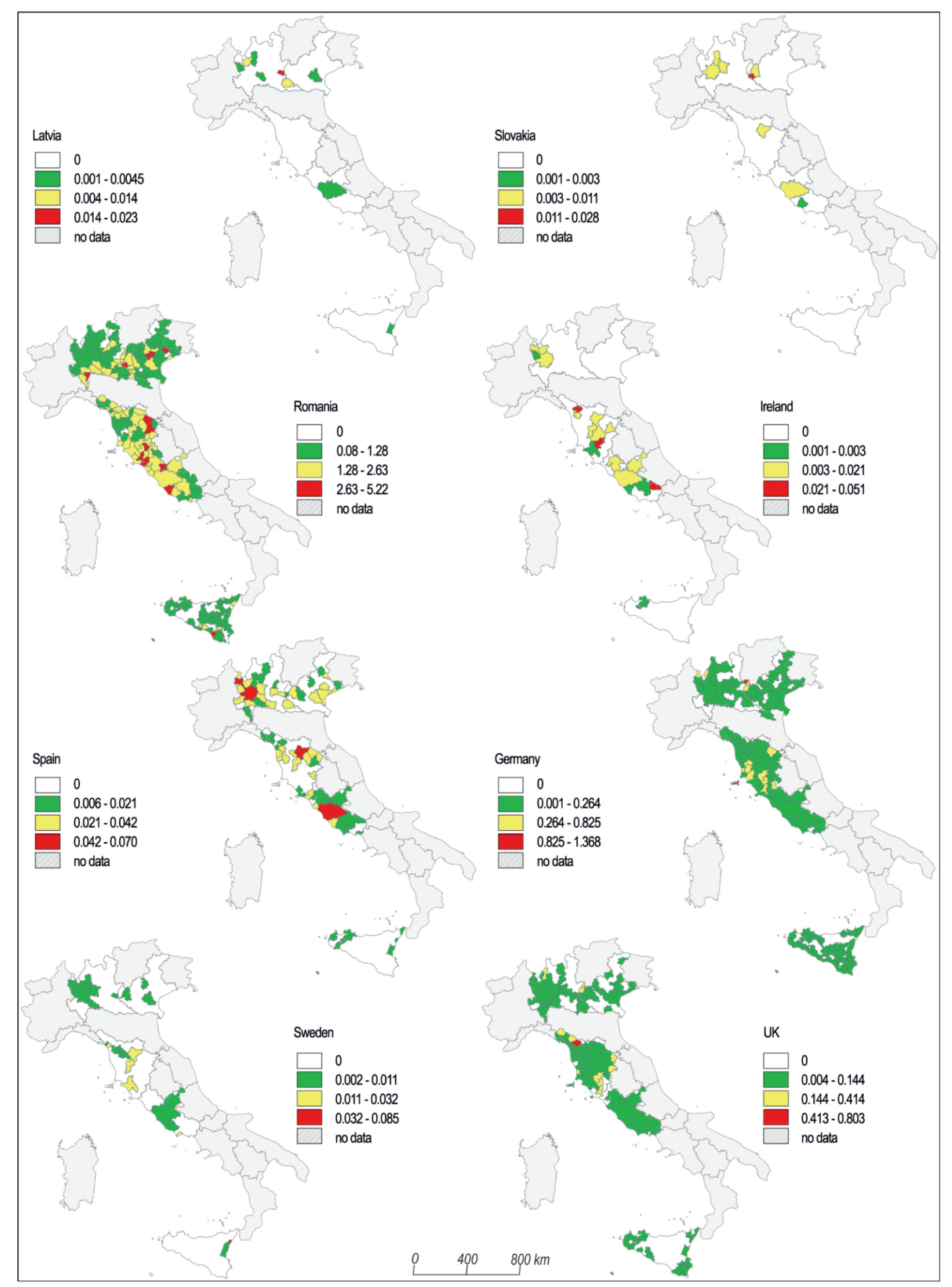

Fig 2. Rate of immigrants in percent over Italian population from 8 EU-member countries to LMA of Lombardy, Veneto, Tuscany, Lazio and Sicily. Source: Compiled by the authors on Istat census data. 
The highest densities of Group 2 nationalities are found in the MLAs of Milan (Ireland and Spain), Rome (Ireland) and Varese (Ireland). By percentage of resident population, the LMAs of Rome, Milan, Florence and Varese show a marked presence of Spanish immigrants, while the Irish dominate in Barga (including a number of the municipalities in the Serchio Valley and the town of Barga, considered one of the most beautiful in Italy), Montalcino (known for the of medieval village of the same name and for the famous Brunello di Montalcino wine) and Sora. In recent decades, this last area has been marked by an intensification of emigration of Italians to Ireland; still today the largest group of Italians in Ireland comes from the municipality of Casalattico.

For immigrants from Group 3 countries, analysis by spatial density shows a high number of immigrants in the LMAs of Luino (German) and Varese (German, British and Swedish). This high density is due to the presence of the Joint Research Centre (JRC) of the European Commission, where about 1,850 people from every country in Europe work, in the town of Ispra on Lake Maggiore. High densities are also seen in the LMAs of Rome (British), Milan (German and British), Florence (British) and in LMAs that include tourist areas such as Barga (British) in Garfagnana. Barga is considered Italy's most Scottish municipality because of the intense migratory flow from that municipality to Scotland. There is also an intense immigrant presence in the LMAs of Viareggio (British) and Portoferraio (German) on the Tyrrhenian Sea in Tuscany, as well as in the LMA that includes Taormina (German and Swedish) in Sicily, and Salò on Lake Garda (German).

A significant number of immigrants have started businesses and are categorized in the statistics as entrepreneurs, freelancers and self-employed workers. This group, which for purposes of simplicity, we define as entrepreneurs, includes 2,432 immigrants from Germany, 1,760 from the UK and 14,301 from Romania. The entrepreneurs from Germany are widely distributed, but a higher concen- tration of them $(18 \%)$ is in the Milan LMA. There are fewer entrepreneurs from the UK $(1,760)$ but these are also found more concentrated (42\%) in the LMAs of Milan, Florence and Rome. There are 14,301 immigrant entrepreneurs from Romania, who are located especially (45\%) in the LMAs of Milan, Verona, Padua, Florence and Rome.

\section{Labour Market Areas: citizenship and age groups}

LMAs also make it possible to analyse immigrants according to age group: 15-35, 35-64 and over 65, studied in terms of spatial density. For Group 1 and for the 15-34 age group, most are found in the major urban areas of the Po Valley (Figure 3).

For example Varese (Latvian), Milan (Latvian, Romanian and Slovak), Bergamo (Romanian and Slovak), Como (Latvian and Slovak), Verona (Romanian and Slovak), Vicenza (Slovak), Padua (Romanian), Rovigo (Latvian) and smaller, interconnected centres such as Busto Arstizio (Latvian and Slovak), Desenzano del Garda (Latvian and Slovak), Villafranca di Verona (Latvian, Romanian and Slovak), Schio (Slovak), Thiene, Conegliano and San Donà di Piave (Slovak), Castelfranco Veneto, Cittadella and Oderzo (Romanian). The immigrant presence in the LMAs of the other three Italian regions is more sporadic: Pontremoli (Romanian), Viareggio (Slovak and Romanian), Montecatini Terme (Latvian and Romanian), Massa and Portoferraio (Slovak), Rome (Romanian) Pomezia (Romanian and Slovak), and Bagheria (Latvian).

In this age group, the number of employed Romanian immigrants includes 62,232 males and 50,994 females, while students, who are therefore members of a family that moved previously, include 8,420 males and 10,156 females. The census records show 25,186 housewives in this same age group, many of whom may actually be employed as domestic workers without being registered. For the 3564 age group, the major presences in the Po 


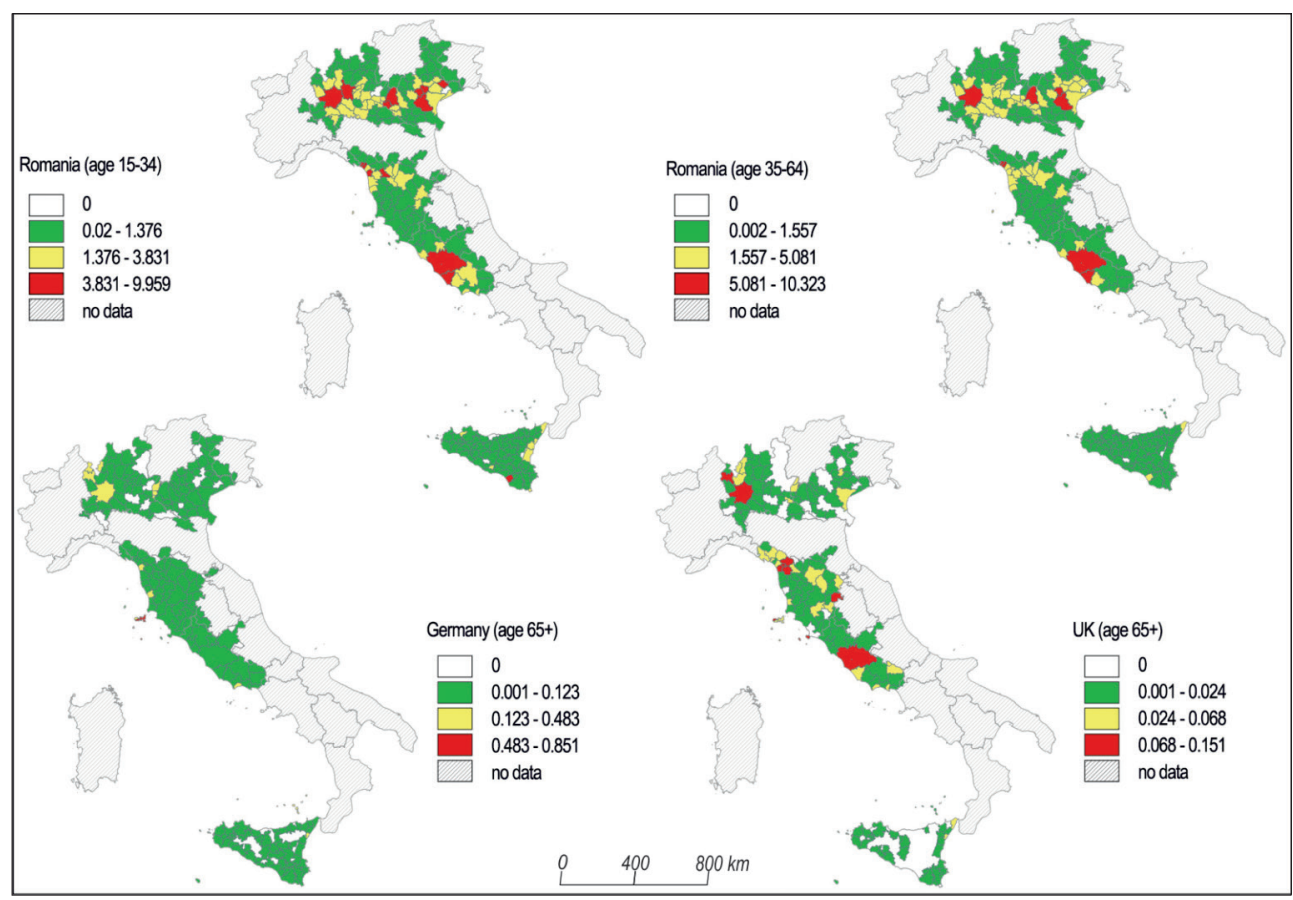

Fig 3. Immigrants from Romania, Germany and UK to LMA of Lombardy, Veneto, Tuscany, Lazio and Sicily. Source: Compiled by the authors on Istat census data.

Valley are in urban areas such as Varese and Como (Latvian), Milan (Latvian, Romanian and Slovak), Verona and Padua (Romanians) and in less urbanized areas such as Luino (Latvian), Villafranca di Verona (Slovak) and Cittadella (Romanian). In the other regions, aside from the LMA of Rome (Romanian), the LMAs of Pontremoli, Viareggio and Pomezia (Romanian) are also noteworthy. For the over 65 age group, immigrants from Romania are present mainly in urban areas such as Milan, Bergamo, Brescia, Verona and Villafranca di Verona, Padua and Cittadella, Florence and Prato, Rome and Pomezia. In Tuscany, immigrants from Romania are present in seaside areas such as the LMAs of Pontremoli and Viareggio, those from Latvia in Sperlonga and those from Slovakia in Civitavecchia.

For Group 2, immigrants from Spain and Ireland are concentrated in the Milan LMA for the 15-34 and 35-64 age groups, while those over 65 are concentrated in the LMA of
Rome. Immigrants from Ireland are concentrated in the LMA of Varese for the 15-34 and 35-64 age groups, and in the seaside towns of Monte Argentario and Sperlonga for those over 65 years.

In Group 3 there is greater continuity by age group in the LMAs where the greatest presence is observed. Immigrants from Germany are more present in the LMAs of Luino, Varese and Milan for the 15-34 and 35-64 age groups. They are also present in Bardolino, Florence and Taormina between 35 and 64 years of age and in Portoferraio (Elba) for all age groups. Immigrants from Sweden are located in the LMAs of Milan and Florence between 15 and 34 years of age, as well as in the coastal centre of the LMA of Sperlonga. They are also present in the LMA of Taormina for all age groups and in the coastal LMAs of Pietrasanta and Sperlonga.

Immigrants from the UK in all age groups are present in the LMAs of Varese and Milan, 
in the 35-64 age group and the over 65 age group in Rome, and in the 35-64 age group in Florence. Immigrants from the UK are also found in the coastal centres of Tuscany Viareggio, for 35-64 and over 65, and Monte Argentario, for over 65. They are also present in Tuscany's inland centres, such as the LMA of Barga (35-64 and over 65) and Montecatini Terme and Cortona (over 65). Pensioner immigrants in the LMAs studied were comprised of 1,316 men and 1,266 women from Germany, 698 men and 687 women from the UK and 49 men and 60 women from Sweden. However, while the Germans are distributed in the LMAs of the major metropolitan areas and along the seaside and the shores of lakes, immigrants from the UK are more concentrated, and therefore more statistically evident, in certain LMAs in Tuscany (Figure 3).

\section{Conclusions}

A precise examination of the immigrant presence in Italy from a selection of EU countries representative of three different situations has shown a close correlation between the various nationalities and the places where they are most concentrated. Within each nationality, furthermore, the presence of immigrants by territory also varies by age. Closer attention to the relationship between each type of immigrant and their chosen destination for migration reveals particularly significant elements, made possible by the work of Istat, which dedicated part of the Census of Population and Housing 2011 to LMA statistics. This is a unique activity carried out by one of the EU's statistical institutes, and one that ought to be continued on a regular basis and extended to as many countries as possible.

The data available for EU countries generally deal with territories whose borders were defined over the centuries, and in Europe often refer to the administrative structure of the Roman Empire. Analysis of LMA data, however, has shown how the phenomenon of migration from the EU countries is directed to specific, clearly identified, highly urban- ized areas of the Po Valley and neighbouring areas. The presence of the JRC in the municipality of Ispra is evident from the presence of numerous young and older immigrants from EU countries who have chosen certain municipalities in the Province of Varese as their place of residence. The LMA of Rome is another draw, whose attractiveness is echoed by the nearby LMAs of Pomezia and Civitavecchia. There there is also a long list of famous resorts along the Tyrrhenian coast where there are mainly immigrants over 65 years old. In addition to the LMAs named in the text, the predominant places include Versilia, Elba and Argentario in Tuscany, Sperlonga in Lazio and Taormina in Sicily.

There is also the significant phenomenon of return migration -Italians who went to work in other EU countries in the 1950s, who became citizens of their adopted countries and then decided to spend their retirement years as re-immigrants in their own places of origin. This phenomenon is particularly evident in the small towns of the Apennines where the presence of return migrants is particularly significant socially and culturally, as well as statistically. It should not be surprising, therefore, that there are small municipalities in the Apennines that celebrate Scottish or Irish festivals, or even a municipal council of a small town in Tuscany that wrote to the Scottish Parliament to express its solidarity on the occasion of the Brexit results. The density of the presence of immigrants has also highlighted some areas where the situation is, or could be, a source of contestation arising from competition for the use of resources and services, whether in the poorer social groups of resident communities, as can happen with Romanian immigrants, or with the rise in real estate values of areas where there are high percentages of pension-age immigrants from the UK and Germany.

Acknowledgement: Research leading to this paper has been done in YMOBILITY (Youth Mobility: maximizing opportunities for individuals, labour markets and regions in Europe) research project funded by the European Commission, Horizon 2020 Programme 2014-2020 under Grant Agreement No. 649491 


\section{REFERENCES}

BALÁž, V. and Williams, A.M. 2002. Central Europe as a buffer zone for international mobility of labour: brain drain or brain waste? In Human mobility in a borderless world? Ed.: Montanari, A., Rome, SGI Home of Geography, 193-223.

Bell, M. and WARD, G. 2000. Comparing temporary mobility with permanent migration. Tourism Geographies 1. (2): 97-107

Benassi, F. and Porciani, L. 2010. The dual demographic profile of migrants in Tuscany. In Demographic aspects of migration. Eds.: Salzmann, T., BARry, E. and RAYMer, J., Wiesbaden, Springer, 209-225.

Bertazzon, L. 2015. Le dinamiche demografiche della popolazione straniera. In Immigrazione straniera in Veneto. A cura dell'Osservatorio Regionale Immigrazione. Venezia-Mestre, Veneto Lavoro, 11-42.

Birindelli, A.M., Farina, P. and Rinaldi, S. 2004. Lombardy's Local Labour Systems and Foreign Immigrants. Statistical Methods and Application, November, 335-338.

BlANGIARDo, G.C. 2016. La popolazione straniera nella realtà lombarda. In Rapporto 2016, gli immigrati in Lombardia. Ed.: Cesareo, V., Milano, Éupolis Lombardia, 19-29.

BoAR, N. 2005. Changes in the human migration patterns in the Maramures region (Romania-Ukraine). Belgeo 1-2. 185-197.

Calafati, A.G. 2005. On the use of Local Labour Systems. Italian Journal of Regional Sciences 4. (1): 1-5.

Calafati, A.G. and Compagnucci, F. 2015. Oltre i sistemi locali del lavoro. Economia Marche 1. 1-30.

Cesareo, V. ed. 2016. Rapporto 2016, gli immigrati in Lombardia. Milano, Éupolis Lombardia.

Colombo, M. and Barabanti, P. 2016. Gli stranieri in Lombardia, capitale umano in crescita. In Rapporto 2016, gli immigrati in Lombardia. Ed.: Cesareo, V., Milano, Éupolis Lombardia, 39-68.

DAHER, L. 2010. Second-generation immigrants in Catania (Sicily): prejudice and relationships with institutions. Working Paper 46. Messina, CIRSDIG.

Drovandi, S. 2015. Le tendenze demografiche della Toscana. Anno 2015. Firenze, Regione Toscana.

Fondazione Leone Moressa - FLM 2016. Il 5,5\% del valore aggiunto nazionale è prodotto dalle imprese condotte da stranieri. Mestre, FLM.

Furmankiewicz, M. 2005. Town-twinning as a factor generating international flows of goods and people. The example of Poland. Belgeo 1-2. 145-162.

Gambuzza, M. and Rasera, M. 2015a. Gli stranieri nel mercato del lavoro regionale. In Immigrazione straniera in Veneto. Ed.: A cura dell'Osservatorio Regionale Immigrazione. Venezia-Mestre, Veneto Lavoro, 43-60.
Gambuzza, M. and Rasera, M. 2015b. Giovani stranieri nel sistema scolastico regionale. In Immigrazione straniera in Veneto. Ed.: A cura dell'Osservatorio Regionale Immigrazione. Venezia-Mestre, Veneto Lavoro, 61-69.

Guerriero, B. 2008. L'immigrazione romena in Lombardia. In Popolazioni che cambiano. A cura di Bergaglio, M., Milano, Franco Angeli, 179-198.

Hannan, K. 2016. After John Urry - a personal reflection. Tourism Geographies 16. (9): 1-4.

IDOS 2016. Centro Studi e Ricerche IDOS e Istituto di Studi Politici San Pio V. Osservatorio Romano sulle Migrazioni - XI Rapporto. Rome, IDOS.

ILIES, A. 2005. The peculiarities of the human mobility frame in the Romanian-Hungarian and RomanianUkrainian border area Belgeo 1-2. 175-183.

Ilies, A., Dehoorne, O. and Horga, I. 2002. Romania. Peculiarities of internal and external human mobility before and after the fall of communism. In Human mobility in a borderless world? Ed.: Montanari, A., Rome, SGI Home of Geography, 95-108.

ILLÉS,. S. 2006. International elderly migration in Hungary. Migracijske i etničke teme 18. (1-2): 53-77.

Ivanov, I.H. 2002a. Migration and the problems ensuing from it for Bulgaria. In Human mobility in a borderless world? Ed.: MontanarI, A., Rome, SGI Home of Geography, 109-118.

KInG, R. and Patterson, G. 1998. Diverse paths: the elderly British in Tuscany. International Journal of Population Geography 4. 157-182.

King, R., Warnes, A.M. and Williams, A.M. 1998. International retirement migration in Europe. International Journal of Population Geography 4. 91-111.

Michalkó, G. 2002. The future of shopping tourism on the periphery of Europe without borders. In Human mobility in a borderless world? Ed.: Montanari, A., Rome, SGI Home of Geography, 143-154.

Michalkó, G. and Rátz, T. 2006. Typically female features in Hungarian shopping tourism. Migracijske i etničke teme 22. (1-2): 79-93.

Montanari, A. and Cortese, A. 1993. Third World immigrants in Italy. In Mass migrations in Europe: the legacy and the future. Ed.: KING, R., London and New York, Belhaven Press, 275-292.

Montanari, A. and Staniscia, B. 2016. Human mobility. An issue of multidisciplinary research. In Global Change and Human Mobility. Ed.: DomínguezMujica, J., Frankfurt, Springer.

Neerman, G. 2010. Immigration in Sicily. Perugia, GCAC Give Competence a Chance.

Sheller, M. 2011. Mobility. Sociopedia.isa 1-12.

Smith, M.P. and Favel, A., eds. 2006. The human face of global mobility: international highly skilled migration in Europe, North America and the Asia-Pacific. New Brunswick, Transaction. 
Stančová, K. 2014. Attracting international research professionals: evidence from Tuscany, Regional Studies, Regional Science 1. (1): 339-346.

Stoenchev, N. and Stoencheva, T. 2002. International migration in Bulgaria within the context of the globalisation of European economy. In Human mobility in a borderless world? Ed.: MontANARI, A., Rome, SGI Home of Geography, 119-122.
URRY, J. 2000. Sociology beyond societies: mobilities for the Twenty-First Century. London, Routledge.

William, A.M. and Hall, C.M. 2000. Tourism and migration: new relationships between production and consumption. Tourism Geographies 1. (2): 5-27. 